\title{
Geochemical and Radiometric studies on the Soils of Wadi Nugrus, South Eastern Desert, Egypt \\ Soliman, M. M. ${ }^{1}$; I. A. Hegab ${ }^{1}$; Salwa S. El-Sayied ${ }^{1}$ and Shimaa A. M. Amer $^{2}$ \\ ${ }^{1}$ Soils, Water and Environment Research Institute, ARC, Giza, Egypt \\ ${ }^{2}$ Nuclear Materials Authority
}

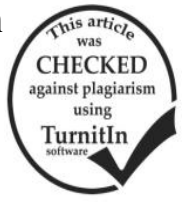

\begin{abstract}
The present work is mainly aimed at evaluating the geochemical properties beside the potential effect of some radioactive sources on the agricultural environment of Wadi Nugrus. The studied area is located at the southern part of the Eastern Desert of Egypt. Eleven soil Profiles were selected to represent Wadi Nugrus plain, The profiles were described morphologically in the field and soil physical, chemical and geochemical properties were evaluated. New results are also obtained in this study about the trace and major elements and the soil radioactivity. The obtained results indicate the following.1- Physical and chemical properties:Soil texture class of Wadi Nugrus area is mostly sand and loamy sand or sandy loom; $\mathrm{Ca} \mathrm{CO}_{3}$ content ranges from 2.5 to $5.8 \%$; organic matter content is very low due to the desertic conditions. $\mathrm{pH}$ values range from 7.49 to 8.81 indicating that this soils are slight to moderately alkaline. ECe values varied from 0.33 to $6.29 \mathrm{dsm}^{-1}$ indicate that the soils differ from non to slightly saline. Soluble cations are dominated by $\mathrm{Na}^{+}$followed by $\mathrm{Ca}^{++}, \mathrm{Mg}^{++}$and $\mathrm{K}^{+}$, while soluble anions followed this order $\mathrm{SO}_{4}{ }_{4}>\mathrm{Cl}^{-}$ $>\mathrm{HCO}_{3} 3 \mathrm{H}\{1$ - Geochemical Properties: The chemical composition of the major oxides distribution in the studied soils reveal that $\mathrm{SiO}_{2}$ is the dominant oxides, this concides with the nature of parent material $\mathrm{Al}_{2} \mathrm{O}_{3}, \mathrm{Fe}_{2} \mathrm{O}_{3}$ and sometimes $\mathrm{CaO}$ and $\mathrm{MgO}$ come after in abundances, followed by $\mathrm{Na}_{2} \mathrm{O}$ and $\mathrm{K}_{2} \mathrm{O}$, while $\mathrm{TiO}_{2}$ and $\mathrm{P}_{2} \mathrm{O}_{5}$ constitutes are less pronounced. Trace elements were also determined and show that most of the determined elements $(\mathrm{Cr}, \mathrm{Cu}, \mathrm{Zn}, \mathrm{Rb}, \mathrm{Y}, \mathrm{pb}$ and $\mathrm{Nb})$ are over the permissible limits obtained by different organization (FAO, UNESCO 1974), except for Ni, Zr, Ba, Sr, Ga and V which were in the range of published data by FAO and UNESCO (1974).The radiometric study carried out on the studied soil samples reveals that the studied soils are in enrichment of radioactive elements (uranium and thorium) the high contents of radioactive elements in the studied soils may be related to the leaching process of uranium from the parent country rocks beside adsorption of uranium on surface of ferruginous materials and / or on also clay surface.
\end{abstract}

Keywords: Geochemical, Radiometric, Trace elements, Does rate, Eastern Desert

\section{INTRODUCTION}

Wadi Nugrus area lies in the southern part of the Eastern Desert of Egypt. It's located $90 \mathrm{~km}$. southwest of Marsa Alam and lies between latitudes $24^{\circ} 40^{\prime}$ and $24^{\circ} 50^{`}$ North and longitudes $34^{\circ} 32^{\backslash}$ and $34^{\circ} 40^{`}$ East (Fig 1). The area could be reached from the Red Sea coast through Wadi El-Gemal area.

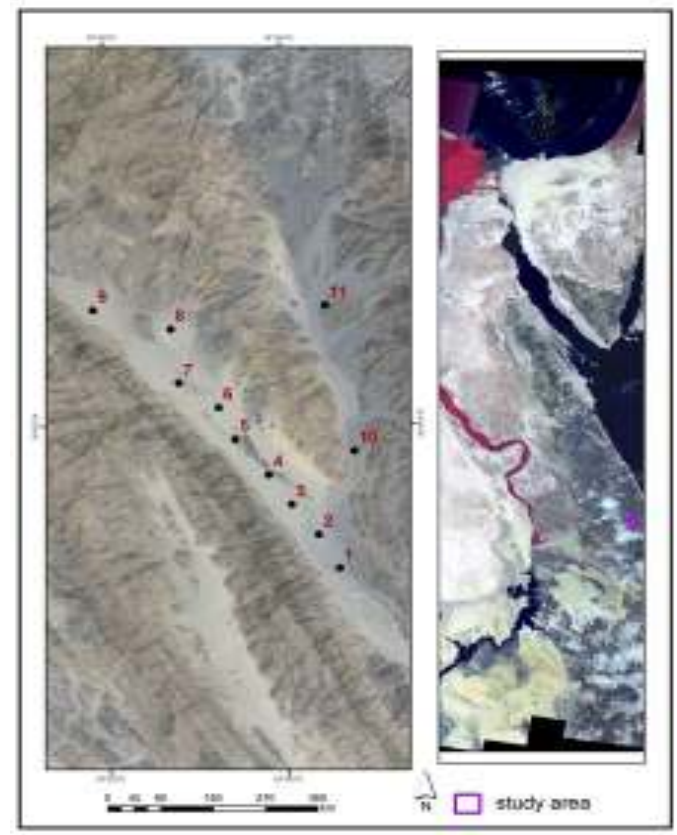

Fig.1. View showing location map of the studied profiles, Wadi Nugrus - Abu Rusheid area, SED, Egypt.

Abu Rushied area and Wadi El-Gemal are very rich in the nuclear materials such as $\mathrm{U}, \mathrm{Th}, \mathrm{Nb}, \mathrm{Ta}, \mathrm{Zr}$,
Be and Ga, Also wadi Abu Rushied area and Wadi ElGemal deposits contain high concentration from nuclear materials and mineralized catalciastic rock (Ibrahim et al., 2000, Oraby et al, 2003 and Ibrahim et al., 2007).

(El-Gaby et al., 1984) revealed that the southern Eastern Desert domain (SED) extends from EgyptianSudanese order to (CED). It's characterized by the presence of ophiolitic belts encompassing between the organic belts trending $\mathrm{NW}$. younger granites are rare in this domain (the striking feature is the ruse occurrence of younger granites). The Migiz -afafit domes and Wadi-Nugrus - Wadi El-Gemal areas, (SED), represent the geologic and tectonic key domains with great significance in the tectonic evolution of the Arabian Nubian Shield, which belongs to the pan African events.

The present work is aming to study the physical, chemical and geochemical properties of Wadi ElNugrus soils beside the potential effect of some radioactive sources on the agricultural environment of Wadi-Nugrus at Abu-Rusheid area, South Eastern Desert of Egypt.

\section{MATERIALS AND METHODS}

On the basis of the obtained topographic map scale 1: 100.000 and the geomorphic map scale 1: 100 000 which are representing the soils of Wadi-Nugrus plain eleven soil profiles were select to represent the soils of Wadi El-Nugrus plain.

These profiles were described following the terminology outlined in the guidelines for soil description (FAO, 2006). Samples representing the vertical morphological variation within each profile were collected, air dried crushed and sieved through a 2 $\mathrm{mm}$ sieve. Then the necessary analyses were preformed 
on the $<2 \mathrm{~mm}$ fractions. and subjected for the following analyses.

1- Physical and chemical analyses of the representative soil samples have been done analyzed using the soil Survey Laboratory Methods Manual (USDA 2004).

2- Geochemical analyses

Total elemental analyses:

The crushed samples were crushed again to 400 mesh grain size using PW 4018100 philips Mini Zirconia mill and the major oxides were measured using conventional wet chemical technique of Shapire and Brannock (1962) with some modifications given by El Reedy et al (1988).

\section{Determination of major oxides}

Si $\mathrm{O}_{2}$, Ti $\mathrm{O}_{2}, \mathrm{Al}_{2} \mathrm{O}_{3}$ and $\mathrm{P}_{2} \mathrm{O}_{5}$ were analyzed using UNICAM UV2/100 Spectrophotometer, while $\mathrm{Na}_{2} \mathrm{O}$ and $\mathrm{K}_{2} \mathrm{O}$ were analyzed using PFP7 flame photometer and $\mathrm{MnO}$ was analyzed by GBC 932 / 933 Atomic Absorption Spectrophotometer. $\mathrm{Fe}_{2} \mathrm{O}, \mathrm{FeO}$, $\mathrm{MgO}$ and $\mathrm{CaO}$ were analyzed by means complex titrimetric technique using EDTA. Total organic matter (T.O.M) was determined by the loss of Ignition method at $550^{\circ}$ C. $\mathrm{H}_{2} \mathrm{O}$ (water of crystallization) was determined by the same method, but the samples were heated to $1000^{\circ} \mathrm{C}$. Moisture content $\left(\mathrm{H}_{2} \mathrm{O}\right)$ and then values were grouped under loss of ignition (L.O. I) category.

Table 1. Morphological description of the studied soil profiles.

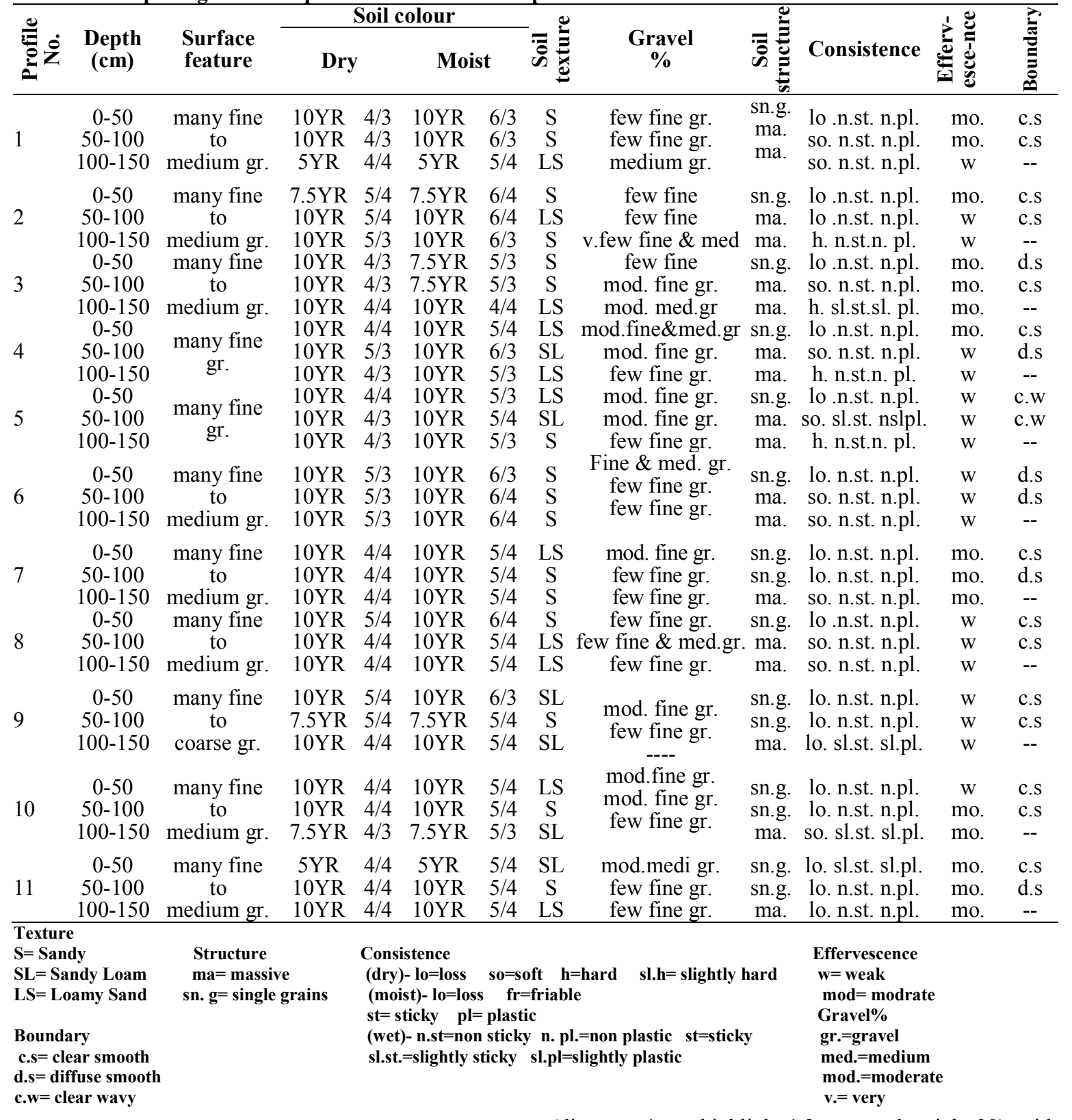

Determination of trace elements

For x-ray fluorescence analysis, a pressed powder pellets were prepared by filling an alumina Cup (diameter $4 \mathrm{~cm}$, highlight $1.2 \mathrm{~mm}$ and weight 39), with $9 \mathrm{~g}$ of crystalline boric acid covered by $1 \mathrm{~g}$, the ground sample, (- 200 mesh grain size) and then pressed under 
12 ton using semi-automatic hydraulic press model HERAOGHTP-40. The trace elements concentrations were calculated from the programs calibration curves, which were set up according to international references materials. The detection limits is the lowest concentration and it is a function of the level of background noise relative to an elements signal (Norrish and Chappell, 1966). The detection limit for the measured elements by XRF technique is $\pm 5 \mathrm{ppm}$.

Determination of $U$, $T h$ and $K$ in soils

The radiometric analysis were carried out in the field by using the handling Eberline Smart portable (ESP, Model 9903) instrument, that courts the total gamma rays emitted from the various rocks in Counts Per Second (CPS) as well as by using multi-channel analysis of X-ray detector (gamma ray spectrometer technique) which measure the $U$ and $T h$ concentration (IAEA, 1979).

\section{RESULTS AND DISCUSSION}

Physical and chemical properties:

Data of physical and chemical analysis of the studied soils of Wadi El-Nugrus area (Tables 2 and 3), showed that the studied soils fall into three soil texture classes for the faire earth, namely sandy, loamy sand and sandy loam where coarse sand, fine sand, silt and clay varies from 19.97 to $15.79,16.12$ to $43.85,3.7$ to 39.42 and 0.85 to $8.15 \%$ respectively. These variations in soil texture are expected due to the differences in soil origin, natural sedimentation pattern and intensity of weathering. The soils are non to slightly calcareous as shown by calcium carbonate content which varies from $2.5 \%$ to $5.8 \%$ Organic matter content varied from $0.07 \%$ to $0.41 \%$. The extremely low contents of organic matter are expected due to prevailing aridity of the region and its very scanty vegetation.

Data presented in Table (3) revealed that the $\mathrm{pH}$ values of the studied soil profiles ranged between 7.49 and 8.81 indicated that these soils are slightly to moderately alkaline. Salinity levels ranged from non saline $\left(0.32 \mathrm{dsm}^{-1}\right)$ and slightly saline $\left(6.29 \mathrm{dsm}^{-1}\right)$. Sodium ions are the predominant soluble cations followed by $\mathrm{Ca}^{++}$and $\mathrm{Mg}^{++}$in all the studied soil sites, while the contents of $\mathrm{K}^{+}$ions are rather low, except for the surface layers of profiles No. 1 and 8 , where $\mathrm{Ca}^{++}$ ion exceeds $\mathrm{Na}^{+}$. Concerning the soluble anions, $\mathrm{SO}^{-} 4$ surpassel $\mathrm{Cl}^{-}$in the non-saline or slightly saline soils, however the reverse was true for the deepest layers of profiles No. 3 and 5 and all layers of profile 7, then both anions are followed by $\mathrm{HCO}_{3}^{-}$.

Table 2. Particle size distribution, texture class, $\mathrm{CaCO3}$ and $\mathrm{O} . \mathrm{M}$ content of the studied soil profiles, Wadi Nugrus - Wadi Abu Rusheid area, SED, Egypt.

\begin{tabular}{|c|c|c|c|c|c|c|c|c|}
\hline \multirow{2}{*}{ Profs. No. } & \multirow{2}{*}{ Depth (cm) } & \multicolumn{4}{|c|}{ Particle size distribution (\%) } & \multirow{2}{*}{$\begin{array}{c}\text { Texture } \\
\text { Class }\end{array}$} & \multirow{2}{*}{$\underset{\%}{\mathrm{CaCO}_{3}}$} & \multirow{2}{*}{$\underset{\%}{\mathbf{O M}}$} \\
\hline & & Clay & Silt & F.S & C.S & & & \\
\hline & $0-50$ & 1.55 & 11.45 & 20.27 & 66.73 & $\mathrm{~S}$ & 3.3 & 0.25 \\
\hline \multirow[t]{3}{*}{1} & $50-100$ & 1.83 & 6.26 & 16.12 & 75.79 & $\mathrm{~S}$ & 3.6 & 0.24 \\
\hline & $100-150$ & 4.32 & 15.68 & 25.08 & 54.92 & LS & 4.1 & 0.21 \\
\hline & $0-50$ & 1.60 & 4.43 & 21.72 & 72.25 & $\mathrm{~S}$ & 4.7 & 0.16 \\
\hline \multirow[t]{3}{*}{2} & $50-100$ & 3.24 & 14.76 & 32.91 & 49.09 & LS & 4.5 & 0.11 \\
\hline & $100-150$ & 1.12 & 6.88 & 34.62 & 57.38 & $\mathrm{~S}$ & 4.3 & 0.11 \\
\hline & $0-50$ & 0.85 & 6.15 & 28.78 & 64.22 & $\mathrm{~S}$ & 5.2 & 0.41 \\
\hline \multirow[t]{3}{*}{3} & $50-100$ & 1.35 & 7.65 & 38.10 & 52.90 & $\mathrm{~S}$ & 5.8 & 0.18 \\
\hline & $100-150$ & 1.85 & 16.15 & 29.51 & 52.49 & LS & 4.8 & 0.12 \\
\hline & $0-50$ & 3.67 & 19.33 & 28.88 & 46.12 & LS & 4.3 & 0.27 \\
\hline \multirow[t]{3}{*}{4} & $50-100$ & 8.15 & 33.25 & 24.60 & 34.0 & SL & 3.7 & 0.15 \\
\hline & $100-150$ & 4.80 & 14.38 & 38.35 & 42.47 & LS & 3.6 & 0.10 \\
\hline & $0-50$ & 4.32 & 11.16 & 30.82 & 53.70 & LS & 2.5 & 0.19 \\
\hline \multirow[t]{3}{*}{5} & $50-100$ & 3.15 & 32.43 & 35.60 & 28.82 & SL & 2.4 & 0.15 \\
\hline & $100-150$ & 3.70 & 13.30 & 43.85 & 39.15 & LS & 3.3 & 0.11 \\
\hline & $0-50$ & 1.44 & 6.60 & 28.71 & 63.25 & $\mathrm{~S}$ & 3.8 & 0.32 \\
\hline \multirow[t]{3}{*}{6} & $50-100$ & 1.25 & 10.80 & 31.0 & 56.95 & $\mathrm{~S}$ & 4.1 & 0.11 \\
\hline & $100-150$ & 1.10 & 6.90 & 37.48 & 54.52 & $\mathrm{~S}$ & 4.6 & 0.12 \\
\hline & $0-50$ & 3.46 & 13.54 & 23.89 & 59.11 & LS & 6 & 0.21 \\
\hline \multirow[t]{3}{*}{7} & $50-100$ & 1.85 & 9.15 & 31.51 & 57.49 & $\mathrm{~S}$ & 5.2 & 0.12 \\
\hline & $100-150$ & 1.15 & 7.57 & 25.08 & 66.20 & $\mathrm{~S}$ & 5.6 & 0.12 \\
\hline & $0-50$ & 0.95 & 10.10 & 28.80 & 60.15 & $\mathrm{~S}$ & 3.6 & 0.31 \\
\hline \multirow[t]{3}{*}{8} & $50-100$ & 1.85 & 15.95 & 33.5 & 48.75 & LS & 2.5 & 0.19 \\
\hline & $100-150$ & 1.62 & 20.38 & 40.20 & 37.80 & LS & 3.3 & 0.15 \\
\hline & $0-50$ & 3.78 & 26.22 & 36.46 & 33.54 & SL & 2.7 & 0.28 \\
\hline \multirow[t]{3}{*}{9} & $50-100$ & 1.00 & 4.93 & 27.50 & 66.57 & $\mathrm{~S}$ & 2.8 & 0.22 \\
\hline & $100-150$ & 6.70 & 38.18 & 35.15 & 19.97 & SL & 3.3 & 0.12 \\
\hline & $0-50$ & 6.35 & 11.65 & 30.30 & 51.70 & $\mathrm{LS}$ & 3.4 & 0.25 \\
\hline \multirow[t]{3}{*}{10} & $50-100$ & 1.12 & 7.84 & 30.14 & 60.90 & $\mathrm{~S}$ & 4.3 & 0.13 \\
\hline & $100-150$ & 7.18 & 39.42 & 31.80 & 21.60 & SL & 5.3 & 0.07 \\
\hline & $0-50$ & 5.72 & 28.88 & 28.5 & 36.90 & SL & 5.2 & 0.23 \\
\hline \multirow[t]{2}{*}{11} & $50-100$ & 0.85 & 3.70 & 36.7 & 58.75 & $\mathrm{~S}$ & 5.3 & 0.17 \\
\hline & $100-150$ & 3.72 & 11.28 & 22.4 & 62.60 & LS & 5.7 & 0.10 \\
\hline
\end{tabular}

S: Sand, SL: Sandy loam and LS: Loamy sand 
Soliman, M. M. et al.

Table 3. Chemical composition of major oxides, Wadi Nugrus - Wadi Abu Rusheid area, "SED, Egypt.

\begin{tabular}{|c|c|c|c|c|c|c|c|c|c|c|c|}
\hline \multirow{2}{*}{$\begin{array}{l}\text { Profiles } \\
\text { No. }\end{array}$} & \multirow{2}{*}{$\begin{array}{l}\text { Depth } \\
\text { (cm) }\end{array}$} & \multirow{2}{*}{ PH } & \multirow{2}{*}{$\begin{array}{c}\mathrm{ECe} \\
\left(\mathrm{dSm}^{-1}\right)\end{array}$} & \multicolumn{4}{|c|}{ Cations (meq/L) } & \multicolumn{4}{|c|}{ Anions (meq/L) } \\
\hline & & & & $\mathrm{Ca}^{++}$ & $\mathbf{M}_{9}^{++}$ & $\mathrm{Na}^{+}$ & $\mathbf{K}^{+}$ & $\mathrm{CO}_{3}^{=}$ & $\mathrm{HCO}_{3}^{-}$ & $\mathrm{Cl}^{-}$ & $\mathrm{SO}_{4}^{=}$ \\
\hline \multirow{3}{*}{1} & $0-50$ & 7.62 & 1.05 & 4.01 & 3.00 & 2.90 & 0.35 & 0.00 & 1.28 & 1.40 & 7.58 \\
\hline & $50-100$ & 7.60 & 1.67 & 5.00 & 4.00 & 7.40 & 0.29 & 0.00 & 1.80 & 5.96 & 8.94 \\
\hline & $100-150$ & 7.60 & 1.52 & 3.00 & 2.00 & 10.18 & 0.22 & 0.00 & 1.36 & 5.22 & 8.82 \\
\hline \multirow{3}{*}{2} & $0-50$ & 7.74 & 0.9 & 3.20 & 2.1 & 3.50 & 0.50 & 0.00 & 1.50 & 2.50 & 5.00 \\
\hline & $50-100$ & 7.78 & 0.48 & 1.94 & 1.50 & 2.60 & 0.10 & 0.00 & 0.40 & 1.90 & 2.50 \\
\hline & $100-150$ & 7.75 & 1.06 & 2.20 & 2.70 & 5.98 & 0.22 & 0.00 & 3.50 & 3.22 & 4.38 \\
\hline \multirow{3}{*}{3} & $0-50$ & 7.94 & 0.27 & 0.65 & 0.50 & 1.45 & 0.10 & 0.00 & 0.25 & 0.85 & 1.60 \\
\hline & $50-100$ & 7.97 & 0.48 & 1.59 & 1.03 & 2.15 & 0.03 & 0.00 & 1.12 & 1.56 & 2.12 \\
\hline & $100-150$ & 7.73 & 1.11 & 2.00 & 2.30 & 6.56 & 0.52 & 0.00 & 1.25 & 5.20 & 5.12 \\
\hline \multirow{3}{*}{4} & $0-50$ & 7.97 & 0.42 & 0.75 & 1.00 & 2.35 & 0.10 & 0.00 & 0.25 & 1.75 & 2.20 \\
\hline & $50-100$ & 7.75 & 0.53 & 1.85 & 0.30 & 2.95 & 0.20 & 0.00 & 0.35 & 1.86 & 3.10 \\
\hline & $100-150$ & 7.88 & 0.52 & 1.82 & 0.37 & 2.90 & 0.21 & 0.00 & 0.10 & 1.90 & 3.20 \\
\hline \multirow{3}{*}{5} & $0-50$ & 8.03 & 0.32 & 0.85 & 0.33 & 1.92 & 0.10 & 0.00 & 0.05 & 1.10 & 2.05 \\
\hline & $50-100$ & 7.86 & 0.35 & 0.90 & 0.50 & i.so & 0.20 & 0.00 & 0.42 & 1.23 & 1.85 \\
\hline & $100-150$ & 7.53 & 0.57 & 0.80 & 1.77 & 2.88 & 0.23 & 0.00 & 0.30 & 1.83 & 1.55 \\
\hline \multirow{3}{*}{6} & $0-50$ & 7.80 & 0.62 & 2.12 & 1.03 & 2.90 & 0.15 & 0.00 & 1.23 & 2.05 & 2.95 \\
\hline & $50-100$ & 7.80 & 1.75 & 4.50 & 5.50 & 7.80 & 0.83 & 0.00 & 1.00 & 4.35 & 12.67 \\
\hline & $100-150$ & 8.04 & 0.40 & 1.50 & 0.75 & 2.31 & 0.20 & 0.00 & 0.16 & 1.06 & 3.00 \\
\hline \multirow{3}{*}{7} & $0-50$ & 8.10 & 0.50 & 2.31 & 0.75 & 4.50 & 0.14 & 0.00 & 1.60 & 4.00 & 2.10 \\
\hline & $50-100$ & 8.81 & 0.93 & 4.62 & 1.52 & 5.20 & 0.28 & 0.00 & 0.62 & 7.00 & 3.00 \\
\hline & $100-150$ & 7.65 & 0.85 & 2.70 & 2.01 & 4.62 & 1.06 & 0.00 & 1.80 & 5.00 & 2.89 \\
\hline \multirow{3}{*}{8} & $0-50$ & 8.06 & 1.04 & 4.00 & 3.00 & 2.92 & 0.39 & 0.00 & 1.25 & 1.35 & 7.71 \\
\hline & $50-100$ & 7.81 & 0.36 & 1.35 & 0.27 & 1.95 & 0.03 & 0.00 & 0.10 & 1.45 & 2.05 \\
\hline & $100-150$ & 8.26 & 1.02 & 3.21 & 1.22 & 5.65 & 0.12 & 0.00 & 0.70 & 3.15 & 6.35 \\
\hline \multirow{3}{*}{9} & $0-50$ & 7.80 & 6.59 & 6.50 & 11.50 & 47.77 & 0.33 & 0.00 & 3.50 & 50.21 & 12.39 \\
\hline & $50-100$ & 7.49 & 2.75 & 3.50 & 2.00 & 21.93 & 0.45 & 0.00 & 2.12 & 8.66 & 17.10 \\
\hline & $100-150$ & 7.58 & 0.86 & 1.95 & 1.09 & 5.35 & 0.21 & 0.00 & 1.40 & 3.35 & 3.85 \\
\hline \multirow{3}{*}{10} & $0-50$ & 7.87 & 0.88 & 2.45 & 2.12 & 4.12 & 0.11 & 0.00 & 0.85 & 2.85 & 5.10 \\
\hline & $50-100$ & 8.08 & 0.34 & 0.90 & 0.80 & 1.55 & 0.15 & 0.00 & 0.05 & 1.50 & 1.85 \\
\hline & $100-150$ & 8.02 & 0.53 & 1.73 & 0.82 & 2.50 & 0.12 & 0.00 & 0.57 & 1.60 & 3.00 \\
\hline \multirow{3}{*}{11} & $0-50$ & 7.82 & 0.72 & 3.10 & 1.63 & 3.47 & 0.16 & 0.00 & 0.10 & 2.85 & 4.56 \\
\hline & $50-100$ & 7.92 & 0.78 & 2.15 & 1.89 & 3.65 & 0.11 & 0.00 & 1.17 & 2.65 & 3.98 \\
\hline & $100-150$ & 7.50 & 0.34 & 1.20 & 0.58 & 1.50 & 0.12 & 0.00 & 0.50 & 0.95 & 1.95 \\
\hline
\end{tabular}

"SED= South Eastern Desert

Geochemical Studies:

The chemical composition and the content of elements may give some informations about the nature of sediments and minerals forming the soil matrix. For a certain element, this content may vary from soil to soil according to its origin, ie, parent material soil forming process; etc. The role of parent material in determining the total content of elements inherited by soil and the consequent modifications resulting in their distribution could be extrapolated from the results presented herein. Table (3) gives the values as percent of ignited soil for each element in the subsequent layers of the investigated soil profiles. The table shows that the elements distribution is as follows.

Major Oxides:

Silica $\left(\mathrm{SiO}_{2}\right)$ content is the major component in all the studied soil profiles representing Wadi Nugrus. Its content ranges from $47.47 \%$ to $68.55 \%$ with different treads in each soil profile layers. The increase in silica content for the studied soils of wadi Nugrus may be due to the presence of a higher content of
Kaolinite and illite clay minerals (as detected from the XRD analysis), in addition to the presence of more quartz and feldspars minerals.

Alumina is the second abundant constituent, of $\mathrm{Al}_{2} \mathrm{O}_{3}$ in the studied soils may be due to its high content of Al-bearing minerals. The high contents of $\mathrm{SiO}_{2}$ and $\mathrm{Al}_{2} \mathrm{O}_{3}$ may give another indication to the dominant arid condition, denoting the prevailing weathering process during the formatting of these soils.

Aluminum concentration in the studied soil samples varies between $8.84 \%$ and $14.17 \%$ (Table 4), which is higher than the equivalent world wide range obtained by FAO and UNESCO (1974).

Titanium oxides $\left(\mathrm{TiO}_{2}\right)$ content was very low and ranged in a narrow limit between $0.21 \%$ and 0.97 $\%$ the lowest value was formed in

The surface layer of profile 10, where the highest value was detected in the subsurface layer of profile 4 . $\mathrm{TiO}_{2}$ content values fall in the world equivalent range obtained by FAO and UNESCO (1974). 
Table 4. Major oxides (\%) analysis of the Wadi Nugrus - Wadi Abu Rusheid area, SED, Egypt

\begin{tabular}{|c|c|c|c|c|c|c|c|c|c|c|c|c|c|c|}
\hline 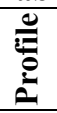 & 产 & ڤ̊ำ & O̊ & $\overbrace{0}^{0}$ & ర్ల్ & 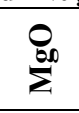 & ְై & ్ְ & શิ & 气̊ & $\stackrel{\varrho}{\Xi}$ & 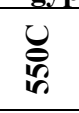 & Ð & $\stackrel{\text { ज्ञ }}{\stackrel{\theta}{\theta}}$ \\
\hline \multirow{4}{*}{$\bar{a}$} & $00-0.50$ & 66.76 & 0.77 & 10.42 & 7.2 & 4.2 & 3 & 3.44 & 2.58 & 0.102 & 0.09 & 0.81 & 0.47 & 99.84 \\
\hline & $0.50-1.0$ & 62.95 & 0.46 & 11.51 & 4.8 & 7 & 3 & 4.55 & 2.68 & 1.06 & 0.28 & 0.82 & 0.66 & 99.77 \\
\hline & $1.0-1.50$ & 62.74 & 0.99 & 10.56 & 6.4 & 8.4 & 3 & 3.29 & 2.01 & 0.102 & 0.82 & 0.59 & 0.67 & 99.1 \\
\hline & Average & 64.15 & 0.74 & 10.83 & 18.4 & 6.53 & 3 & 3.76 & 2.42 & 0.42 & 0.38 & 0.74 & 0.60 & 99.57 \\
\hline \multirow{4}{*}{ 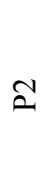 } & $00-0.50$ & 63.25 & 0.22 & 12.07 & 4 & 7 & 4 & 5.06 & 2.68 & 0.04 & 0.31 & 0.54 & 0.47 & 99.63 \\
\hline & $0.50-1.0$ & 63.5 & 0.37 & 11.84 & 4.4 & 7 & 3 & 5.4 & 1.76 & 0.04 & 0.3 & 0.63 & 1.13 & 99.37 \\
\hline & $1.0-1.50$ & 61.99 & 0.34 & 13.04 & 4 & 7 & 3 & 4.89 & 2.10 & 1.45 & 0.27 & 0.6 & 0.86 & 99.54 \\
\hline & Average & 72.47 & 0.31 & 12.32 & 4.13 & 7 & 3.3 & 5.11 & 2.18 & 0.51 & 0.29 & 0.59 & 0.82 & 99.51 \\
\hline \multirow{4}{*}{$\hat{n}$} & $00-0.50$ & 59.82 & 0.8 & 10.90 & 6.4 & 9.8 & 4 & 4.05 & 2.20 & 0.122 & 0.01 & 0.54 & 1.04 & 99.96 \\
\hline & $0.50-1.0$ & 63.24 & 0.7 & 8.84 & 2.8 & 11.2 & 4. & 4.72 & 2.68 & 0.102 & 0.02 & 0.34 & 0.32 & 99.06 \\
\hline & $1.0-1.50$ & 62.24 & 0.54 & 13.27 & 5.2 & 5.6 & 4 & 4.05 & 2.29 & 0.613 & 0.03 & 0.57 & 0.86 & 99.52 \\
\hline & Average & 89 & 0.68 & 11.00 & 4.8 & 8.86 & 4 & 4.27 & 2.39 & 0.279 & 0.02 & 0.48 & 0.74 & 99.51 \\
\hline \multirow{4}{*}{ I } & $00-0.50$ & 62.39 & 0.47 & 11.13 & 7.2 & 5.6 & 4 & 4.55 & 2.39 & 0.102 & 0.018 & 0.56 & 0.93 & 99.53 \\
\hline & $0.50-1.0$ & 62.39 & 0.97 & 11.84 & 6.4 & 7 & 3 & 3.89 & 2.68 & 0.081 & 0.02 & 0.42 & 0.94 & 99.30 \\
\hline & $1.0-1.50$ & 62.24 & 0.49 & 9.9 & 7.2 & 7.2 & 3 & 3.29 & 2.01 & 0.102 & 0.03 & 0.92 & 1.16 & 99.48 \\
\hline & Average & 62.34 & 0.64 & 10.96 & 6.9 & 6.6 & 3.3 & 3.91 & 2.36 & 0.095 & 0.022 & 0.63 & 1.01 & 99.44 \\
\hline \multirow{4}{*}{$\curvearrowleft$} & $00-0.50$ & 67.35 & 0.72 & 11.09 & 4 & 4 & 3 & 2.84 & 2.2 & 0.26 & 0.05 & 0.46 & 0.77 & 99.38 \\
\hline & $0.50-1.0$ & 64.57 & 0.43 & 12.52 & 7.2 & 7.2 & 2 & 3.29 & 2.2 & 0.102 & 0.01 & 0.54 & 0.74 & 99.59 \\
\hline & $1.0-1.50$ & 64.68 & 0.49 & 11.02 & 8.4 & 8.4 & 2 & 3.29 & 2.01 & 0.143 & 0.03 & 0.66 & 0.84 & 99.62 \\
\hline & Average & 65.53 & 0.54 & 11.54 & 6.5 & 6.53 & 2.3 & 3.14 & 2.13 & 0.17 & 0.03 & 0.55 & 0.78 & 99.53 \\
\hline \multirow{4}{*}{2} & $00-0.50$ & 62.77 & 0.73 & 11.46 & 7.2 & 7.2 & 3 & 3.29 & 2.2 & 0.102 & 0.05 & 0.62 & 1.07 & 99.65 \\
\hline & $0.50-1.0$ & 65.63 & 0.73 & 12.33 & 5.6 & 5.6 & 3. & 2.7 & 1.82 & 0.102 & 0.01 & 0.89 & 1.16 & 99.72 \\
\hline & $1.0-1.50$ & 64.35 & 0.59 & 11.43 & 4.4 & 8.4 & 3 & 3.14 & 2.01 & 0.28 & 0.03 & 0.92 & 1.2 & 99.69 \\
\hline & Average & 64.25 & 0.68 & 11.74 & 5.73 & 7.06 & 3 & 3.04 & 2.01 & 0.161 & 0.03 & 0.81 & 4.74 & 99.68 \\
\hline \multirow{4}{*}{$\hat{a}$} & $00-0.50$ & 59.21 & 0.41 & 13.28 & 7.4 & 8.4 & 3 & 2.99 & 2.2 & 0.225 & 0.20 & 0.88 & 1.1 & 99.5 \\
\hline & $0.50-1.0$ & 60.28 & 0.70 & 12.61 & 3.6 & 11.2 & 4 & 3.14 & 2.2 & 0.122 & 0.30 & 0.82 & 0.71 & 99.37 \\
\hline & $1.0-1.50$ & 62.61 & 0.39 & 12.82 & 5.2 & 7 & 3 & 3.29 & 2.2 & 0.122 & 0.50 & 0.98 & 1.02 & 99.08 \\
\hline & Average & 60.7 & 0.5 & 12.90 & 5.4 & 8.86 & 3.33 & 3.14 & 2.2 & 0.156 & 0.33 & 0.89 & 0.94 & 99.32 \\
\hline \multirow{4}{*}{$\stackrel{\infty}{\infty}$} & $00-0.50$ & 65.82 & 0.42 & 11.61 & 6.8 & 5.6 & 2 & 2.57 & $2 . .01$ & 0.143 & 0.10 & 0.93 & 1.37 & 99.60 \\
\hline & $0.50-1.0$ & 59.92 & 0.33 & 13.35 & 6 & 7 & 3 & 4.05 & 1.46 & 0.163 & 0.30 & 0.82 & 1.1 & 99.69 \\
\hline & $1.0-1.50$ & 47.47 & 0.50 & 12.97 & 19.17 & 7 & 3 & 3.29 & 1.58 & 2.29 & 0.20 & 0.86 & 1.41 & 99.6 \\
\hline & Average & 57.73 & 0.41 & 12.64 & 10.65 & 6.53 & 2.66 & 3.30 & 1.68 & 0.86 & 0.2 & 0.87 & 1.29 & 99.63 \\
\hline \multirow{4}{*}{ ฉ } & $00-0.50$ & 65.65 & 0.34 & 13 & 5.6 & 5.6 & 2 & 2.57 & 1.58 & 2.11 & 0.06 & 0.9 & 1.29 & 99.54 \\
\hline & $0.50-1.0$ & 63.63 & 0.57 & 12 & 5.2 & 7 & 3 & 3.14 & 12.68 & 0.286 & 0.04 & 0.93 & 0.62 & 99.59 \\
\hline & $1.0-1.50$ & 62.17 & 0.28 & 14.17 & 6.4 & 7 & 3 & 2.7 & 1.64 & 0.613 & 0.05 & 0.73 & 1.14 & 99.96 \\
\hline & Average & 63.82 & 0.40 & 13.05 & 5.73 & 6.53 & 2.66 & 2.80 & 5.3 & 1.00 & 0.05 & 0.85 & 1.01 & 99.69 \\
\hline \multirow{4}{*}{$\frac{0}{a}$} & $00-0.50$ & 68.53 & 0.21 & 13.72 & 4 & 4.2 & 2 & 2.7 & 2.39 & 0.204 & 0.02 & 0.7 & 0.84 & 99.63 \\
\hline & $0.50-1.0$ & 65.75 & 0.37 & 12.1 & 4.8 & 5.6 & 2 & 4.05 & 2.39 & 0.143 & 0.47 & 0.71 & 0.7 & 99.21 \\
\hline & $1.0-1.50$ & 66.63 & 0.33 & 12.14 & 3.6 & 5.6 & 4 & 2.7 & 2.68 & 0.122 & 0.04 & 0.66 & 0.56 & 99.38 \\
\hline & Average & 66.97 & 0.30 & 12.65 & 4.13 & 5.13 & 2.66 & 3.15 & 2.48 & 0.823 & 0.176 & 0.69 & 0.7 & 99.40 \\
\hline \multirow{4}{*}{$\bar{a}$} & $00-0.50$ & 66.92 & 0.64 & 11.35 & 6.4 & 5.6 & 2 & 3.14 & 1.52 & 0.143 & 0.02 & 1.23 & 0.73 & 99.94 \\
\hline & $0.50-1.0$ & 67.92 & 0.37 & 11.90 & 4.8 & 5.6 & 2 & 2.99 & 2.2 & 0.081 & 0.08 & 0.89 & 0.94 & 99.55 \\
\hline & $1.0-1.50$ & 62.96 & 0.55 & 12.93 & 5.6 & 5.6 & 4 & 2.84 & 1.64 & 0.163 & 0.09 & 1.23 & 1.33 & 99.34 \\
\hline & Average & 65.93 & 0.52 & 12.06 & 5.6 & 5.6 & 2.6 & 2.99 & 1.79 & 0.129 & 0.06 & 1.14 & 1.00 & 99.61 \\
\hline
\end{tabular}


Iron $\mathrm{Fe}_{2} \mathrm{O}_{3}$ content ranges from $2.80 \%$ to $19.17 \%$ the relatively high content of $\mathrm{Fe}_{2} \mathrm{O}_{3}$ may be related to the presence of discrete clay minerals in these soil samples as verified from the XRD analysis.

$\mathrm{CaO}$ is present in all the analyzed samples and ranged from $4.20 \%$ to $11.20 \%$. The wide range of $\mathrm{CaO}$ in the studied soils is related to variations in $\mathrm{Ca} \mathrm{CO}_{3}$ content and $\mathrm{CaO}$ bearing minerals.

$\mathrm{MgO}$ content in the studied soils ranges from narrow limit 2.00 to $4.00 \%$. The narrow range of $\mathrm{Mg} \mathrm{O}$ content may indicate that $\mathrm{Mg}$ content of soils and $\mathrm{Mg}$ bearing minerals lie within a narrow range.

$\mathrm{NaO}$ is present in all the examined soil samples but in minor content. It varies from $2.57 \%$ to $5.40 \%$ which may be ascribed to possible presence of Nabearing minerals such as Na-feldspars (alibte).

The $\mathrm{K}_{2} \mathrm{O}$ content ranges between $1.46 \%$ and $2.68 \%$ for the studied soil profiles. The highest content of $\mathrm{K}_{2} \mathrm{O}$ may be due to the relatively high contents of hydrous mica and other K-bearing minerals.

$\mathrm{P}_{2} \mathrm{O}_{5}$ is generally, present in very low content for the studied soils ranging from $0.04 \%$ to $2.29 \%$ with an irregular distribution pattern with depth. The low content of $\mathrm{P}_{2} \mathrm{O}_{5}$ in which Wadi Nugrus soils may be due to the nature of these soils.

Loss of ignition (L. O. I):

The determined water content lost between $110^{\circ}$ $\mathrm{c}$ and $1000^{\circ} \mathrm{c}$ was found to range from $0.09 \%$ and $1.32 \%$ for the studied soil profiles. The relatively lower water content in the soils of Wadi Nugurs area is possible related to their lower content of expanding 2:1 clay mineral species.
In conclusion, while the nature of parent material is the major factor determining the general status of elements in the studied soils, the distribution of these elements within the different layers of profiles is a function of the soils characters.

\section{Trace elements geochemistry:}

In the fine grained sediments, such as soils, silt and clay fractions, trace elements may be carried into solutions as fluiddy divide suspended detritus and / or in lattic position with existing minerals. The abundance and distribution of the trace elements in Wadi Nugrus soils are listed in Table (5), the following is, however, a short account of some of the analyzed trace elements.

Chromium $(\mathrm{Cr})$ concentration in the studied soil profiles varied from $137 \mathrm{mg} \mathrm{kg}^{-1}$ in the surface layer of profile 5 , and $526 \mathrm{mg} \mathrm{kg}^{-1}$ in the deepest layer of profile 1 with an average ranged from 162.3 to $370.7 \mathrm{mg} \mathrm{kg}^{-1}$. chromium content in the studied soils lie over the world geometric mean of $72 \mathrm{mg} \mathrm{kg}^{-1}$ published by FAO and UNESCO (1974). Also, the high content of $\mathrm{Cr}$ in the studied soils may be due to the soils are inherited from parent rocks so, may be drived from mafric and volcanic rocks (Aubert and pinto, 1977).

The concentration of $\mathrm{Ni}$ with studied soil samples ranged from 51.0 to $269.0 \mathrm{~kg}^{-1}$ with an average ranged between 75.3 to $203.3 \mathrm{mg} \mathrm{kg}^{-1}$, which is in the range of the published data by FAO and UNESCO (1974), (5-700 mg kg $\left.{ }^{-1}\right)$.

Copper $(\mathrm{Cu})$ concentration in the studied soil profiles ranges from 49 to $79 \mathrm{mg} \mathrm{kg}^{-1}$ with an average varied from 58.3 to $72.3 \mathrm{mg} \mathrm{kg}^{-1}$, which is higher than the world geometric mean of $33 \mathrm{mg} \mathrm{kg}^{-1}$ obtained by FAO and UNESCO (1974).

Table 5. Trace elements analysis for soil samples, Wadi Nugrus - Wadi Abu Rusheid area, SED, Egypt.

\begin{tabular}{|c|c|c|c|c|c|c|c|c|c|c|c|c|c|c|}
\hline \multirow{2}{*}{$\begin{array}{l}\text { Profile } \\
\text { No: }\end{array}$} & \multirow{2}{*}{$\begin{array}{c}\text { Depth/ } \\
\text { m }\end{array}$} & \multicolumn{13}{|c|}{ Trace Elements } \\
\hline & & $\mathrm{Cr}$ & $\mathbf{N i}$ & $\mathbf{C u}$ & $\mathbf{Z n}$ & $\mathbf{Z r}$ & $\mathbf{R b}$ & $\mathbf{Y}$ & $\mathbf{B a}$ & $\mathbf{P b}$ & $\mathbf{S r}$ & Ga & $\mathbf{V}$ & $\mathbf{N b}$ \\
\hline \multirow{7}{*}{$\bar{a}$} & $00-0.50$ & 215 & 99 & 59 & 280 & 823 & 335 & 70 & 52 & 98 & 86 & Ad & 25 & 31 \\
\hline & $0.50-1.0$ & 222 & 119 & 71 & 446 & 1048 & 299 & 89 & 67 & 149 & 105 & 2 & 34 & 39 \\
\hline & $1.0-1.50$ & 526 & 153 & 66 & 344 & 516 & 350 & 45 & 54 & 228 & 53 & 3 & 38 & 19 \\
\hline & Average & 322 & 123.7 & 65.3 & 356.7 & 795.7 & 328 & 68 & 57.7 & 158.3 & 81.3 & 1.7 & 32.3 & 29.7 \\
\hline & $00-0.50$ & 217 & 137 & 68 & 944 & 446 & 313 & 39 & 41 & 136 & 46 & 2 & 22 & 17 \\
\hline & $0.50-1.0$ & 299 & 267 & 66 & 330 & 359 & 249 & 31 & 74 & 142 & 37 & 2 & 40 & 14 \\
\hline & $1.0-1.50$ & 222 & 125 & 74 & 457 & 267 & 305 & 32 & 77 & 189 & 37 & 3 & 41 & 14 \\
\hline \multirow[t]{4}{*}{ 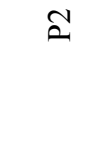 } & Average & 246 & 176.3 & 63.9 & 571 & 357.3 & 289 & 34 & 64 & 155.7 & 40 & 2.3 & 34.3 & 15 \\
\hline & $00-0.50$ & 286 & 193 & 68 & 504 & 324 & 282 & 28 & 105 & 124 & 33 & Ad & 57 & 12 \\
\hline & $0.50-1.0$ & 145 & 51 & 53 & 184 & 258 & 287 & 22 & 68 & 64 & 26 & Ad & 36 & 10 \\
\hline & $1.0-1.50$ & 273 & 190 & 78 & 413 & 457 & 325 & 39 & 82 & 143 & 17 & 2 & 45 & 17 \\
\hline \multirow[t]{4}{*}{ 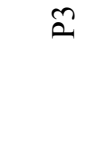 } & Average & 234.7 & 144.7 & 66.3 & 367 & 346.3 & 298 & 29.7 & 85 & 110.3 & 25.3 & 0.7 & 46 & 9.4 \\
\hline & $00-0.50$ & 173 & 100 & 53 & 282 & 249 & 242 & 21 & 92 & 71 & 24 & Ad & 18 & 9 \\
\hline & $0.50-1.0$ & 161 & 53 & 67 & 223 & 251 & 224 & 22 & 76 & 63 & 26 & Ad & 38 & 9 \\
\hline & $1.0-1.50$ & 175 & 106 & 68 & 341 & 226 & 144 & 19 & 181 & 80 & 22 & Ad & 93 & 8 \\
\hline \multirow[t]{4}{*}{ 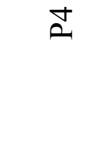 } & Average & 169.7 & 96.3 & 62.7 & 282 & 242 & 203.3 & 20.7 & 116.3 & 71.3 & 24 & Ad & 49.6 & 8.7 \\
\hline & $00-0.50$ & 137 & 70 & 49 & 186 & 241 & 196 & 21 & 79 & 62 & 24 & Ad & 39 & 9 \\
\hline & $0.50-1.0$ & 166 & 98 & 61 & 251 & 345 & 250 & 20 & 103 & 84 & 36 & Ad & 50 & 13 \\
\hline & $1.0-1.50$ & 184 & 121 & 72 & 249 & 268 & 194 & 23 & 107 & 66 & 27 & Ad & 53 & 10 \\
\hline \multirow[t]{4}{*}{$\curvearrowleft$} & Average & 162.3 & 75.3 & 60.7 & 228.7 & 284.7 & 213.3 & 24.7 & 96.3 & 70.7 & 29 & Ad & 47.3 & 10.7 \\
\hline & $00-0.50$ & 223 & 145 & 67 & 373 & 500 & 429 & 43 & 102 & 127 & 50 & 2 & 55 & 19 \\
\hline & $0.50-1.0$ & 206 & 111 & 76 & 1034 & 359 & 171 & 34 & 185 & 120 & 37 & 2 & 88 & 14 \\
\hline & $1.0-1.50$ & 196 & 112 & 64 & 347 & 511 & 305 & 44 & 121 & 133 & 53 & 2 & 63 & 19 \\
\hline 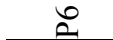 & Average & 211.7 & 122.7 & 69 & 584.7 & 456.7 & 335 & 40.3 & 136 & 126.7 & 46.7 & 2 & 68.7 & 17.3 \\
\hline
\end{tabular}

All Elements are expressed by ppm. $\quad * A d=$ undetermined 
Table 5. Conten.

\begin{tabular}{|c|c|c|c|c|c|c|c|c|c|c|c|c|c|c|}
\hline \multirow{2}{*}{$\begin{array}{l}\text { Profile } \\
\text { No: }\end{array}$} & \multirow{2}{*}{ Depth/ m } & \multicolumn{13}{|c|}{ Trace Elements } \\
\hline & & $\mathrm{Cr}$ & $\mathrm{Ni}$ & $\mathbf{C u}$ & Zn & $\mathbf{Z r}$ & $\mathbf{R b}$ & $\mathbf{Y}$ & $\mathbf{B a}$ & $\mathbf{P b}$ & $\mathrm{Sr}$ & Ga & $\mathbf{V}$ & $\mathbf{N b}$ \\
\hline \multirow{4}{*}{$\hat{\imath}$} & $00-0.50$ & 268 & 217 & 62 & 416 & 334 & 356 & 28 & 99 & 111 & 34 & Ad & 56 & 12 \\
\hline & $0.50-1.0$ & 156 & 75 & 64 & 244 & 314 & 237 & 27 & 96 & 78 & 32 & Ad & 49 & 12 \\
\hline & $1.0-1.50$ & 243 & 164 & 79 & 454 & 415 & 334 & 35 & 117 & 197 & 43 & 3 & 66 & 15 \\
\hline & Average & 222.3 & 152 & 68.3 & 371.3 & 355.3 & 309 & 30 & 104 & 128 & 36.3 & 1 & 57 & 13 \\
\hline \multirow{4}{*}{$\infty$} & $00-0.50$ & 395 & 222 & 67 & 300 & 289 & 295 & 25 & 109 & 185 & 29 & 2 & 70 & 11 \\
\hline & $0.50-1.0$ & 336 & 206 & 77 & 287 & 318 & 230 & 27 & 126 & 152 & 33 & 2 & 85 & 12 \\
\hline & $1.0-1.50$ & 381 & 263 & 73 & 344 & 260 & 225 & 22 & 118 & 148 & 27 & 2 & 76 & 10 \\
\hline & Average & 370.7 & 203.3 & 72.3 & 310.3 & 289 & 250 & 24.7 & 117.7 & 161.7 & 29.7 & 2 & 77 & 11 \\
\hline \multirow{4}{*}{ 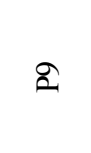 } & $00-0.50$ & 223 & 135 & 65 & 333 & 463 & 263 & 40 & 146 & 102 & 48 & Ad & 76 & 17 \\
\hline & $0.50-1.0$ & 163 & 84 & 65 & 344 & 341 & 407 & 29 & 79 & 114 & 34 & Ad & 44 & 13 \\
\hline & $1.0-1.50$ & 273 & 200 & 74 & 410 & 346 & 238 & 29 & 152 & 149 & 35 & 2 & 82 & 13 \\
\hline & Average & 219.7 & 139.7 & 68 & 362.3 & 383.3 & 302.7 & 32.7 & 125.7 & 121.7 & 39 & 0.7 & 67.3 & 14.3 \\
\hline \multirow{4}{*}{$\stackrel{0}{2}$} & $00-0.50$ & 188 & 103 & 64 & 245 & 370 & 296 & 32 & 72 & 77 & 39 & Ad & 40 & 14 \\
\hline & $0.50-1.0$ & 157 & 80 & 55 & 444 & 207 & 180 & 18 & 99 & 50 & 22 & Ad & 52 & 8 \\
\hline & $1.0-1.50$ & 153 & 67 & 56 & 500 & 790 & 724 & 68 & 57 & 179 & 81 & 2 & 28 & 10 \\
\hline & Average & 166 & 83.3 & 58.3 & 396.3 & 455.7 & 393.7 & 39.3 & 75 & 102 & 47.3 & 0.7 & 40 & 10.7 \\
\hline \multirow{4}{*}{$\overline{2}$} & $00-0.50$ & 214 & 127 & 74 & 527 & 356 & 281 & 31 & 69 & 149 & 35 & 2 & 37 & 13 \\
\hline & $0.50-1.0$ & 244 & 269 & 62 & 213 & 302 & 217 & 26 & 58 & 89 & 30 & Ad & 35 & 11 \\
\hline & $1.0-1.50$ & 203 & 118 & 63 & 299 & 313 & 207 & 27 & 125 & 8.5 & 33 & $\mathrm{Ad}$ & 64 & 12 \\
\hline & Average & 220.3 & 138 & 66.3 & 346.3 & 323.7 & 235 & 28 & 84.3 & 82.1 & 32.7 & 0.7 & 45.3 & 12 \\
\hline
\end{tabular}

$\mathrm{Zn}$ concentration of the studied soils varied from $184 \mathrm{mg} \mathrm{kg}^{-1}$ in the $50-100$ em layer of profile 3 and $1034 \mathrm{mg} \mathrm{kg}^{-1}$ in the subsurface layer of profile 6 , with an average from 228.7 to $584.7 \mathrm{mg} \mathrm{kg}^{-1}$, which is above the world equivalent geometric mean $94 \mathrm{mg} \mathrm{kg}^{-1}$ obtained by FAO and UNESCO (1974) .

Zirconium $(\mathrm{Zr})$ concentration in the investigated soil profiles ranges from 207 to $1047 \mathrm{mg} \mathrm{kg}^{-1}$ with an average varied from 242 to $795.7 \mathrm{mg} \mathrm{kg}^{-1}$, which lie in the obtained range by FAO and UNESCO (1974) of 20 to $2000 \mathrm{mg} \mathrm{kg}^{-1}$.

The Rubidium $(\mathrm{Rb})$ concentration in the studied soils of Wadi Nugrus area ranges between 144 and 724 $\mathrm{mg} \mathrm{kg}^{-1}$, with an average varied from 203.3 to $393.7 \mathrm{mg}$ $\mathrm{kg}^{-1}$, while it is higher than the world geometic range (20-40 $\mathrm{mg} \mathrm{kg}^{-1}$ ).

The concentration of Yttrium (Y) in the studied soils profiles varied from 18 to $89 \mathrm{mg} \mathrm{kg}^{-1}$ with an average ranges from 20.7 and $68.0 \mathrm{mg} \mathrm{kg}^{-1}$. The mean values of the studied soils are above the equivalent world wide concentration of $30 \mathrm{mg} \mathrm{kg}^{-1}$ published by FAO and UNESCO (1974).

Data in Table (4) reveal that the concentration of Barium $(\mathrm{Ba})$ in the studied soil profiles varied from 41 $\mathrm{mg} \mathrm{kg}^{-1}$ to $185 \mathrm{mg} \mathrm{kg}^{-1}$ with an average varies between 57 and $136 \mathrm{mg} \mathrm{kg}^{-1}$ which is considered under the world equivalent geometric mean $460 \mathrm{mg} \mathrm{kg}^{-1}$ obtained by FAO and UNSECO (1974).

The lead $(\mathrm{pb})$ concentration in the studied soil profiles were varied from 50 to $228 \mathrm{mg} \mathrm{kg}^{-1}$, with an average ranges from 70.7 to $161 \mathrm{mg} \mathrm{kg}^{-1}$. the mean values of lead in the studied area are above the world equivalent geometric mean $\left(19 \mathrm{mg} \mathrm{kg}^{-1}\right)$ obtained by FAO and UNESCO (1974).

Strontium (Sr) concentration values of the studied soils ranged between $17 \mathrm{mg} \mathrm{kg}^{-1}$ and $105 \mathrm{mg} \mathrm{kg}^{-}$ ${ }^{1}$, with an average values from 24 to $81.3 \mathrm{mg} \mathrm{kg}^{-1}$,

which lie in the world soil ranges $\left(5-3000 \mathrm{mg} \mathrm{kg}^{-1}\right)$ according to FAO and UNSECO (1974).

Data in Table (4) show that the concentration of Gallium $(\mathrm{Ga})$ in the soils of Wadi-Nugrus ranged from 2 to $3 \mathrm{mg} \mathrm{kg}^{-1}$ with an average varied from 0.7 to $2 \mathrm{mg} \mathrm{kg}^{-}$ ${ }^{1}$, which is under the world equivalent geometric mean of $18 \mathrm{mg} \mathrm{kg}^{-1}$ obtained by FAO and UNESCO (1974).

Result in Table (4) reveal that the concentration of vanadium element (V) in the studied soils varied from $18 \mathrm{mg} \mathrm{kg}^{-1}$ and $93 \mathrm{mg} \mathrm{kg}^{-1}$ which lie within the ranges published by FAO and UNESCO (1974) of 7 to $500 \mathrm{mg} \mathrm{kg}^{-1}$.

Data in Table (4) reveal that the Niobium $(\mathrm{Nb})$ concentration in the studied soils of Wadi Nugrus ranged between $8 \mathrm{mg} \mathrm{kg}^{-1}$ and $39 \mathrm{mg} \mathrm{kg}^{-1}$ with an average varies from 8.7 to $29.7 \mathrm{mg} \mathrm{kg}^{-1}$ which is above the world equivalent geometric mean (13 $\mathrm{mg} \mathrm{kg}^{-1}$ ) obtained by FAO and UNESCO (1974).

\section{Radiometric studies:}

Natural radionuclides in agricultural environments were recently explored in order to set levels of environments quality control in Wadi Nugrus area. These radioactive elements may occur naturally in some parent materials drived from rich radioactive rocks, adding fertilizers, especially phosphates rock and $\mathrm{K}$ salts, may add radionuclide to intersively managed soils.

The major radioactivity in rocks is a result of the natural decay of three radioactive sources of uraniumradium family, thorium family and of the radioactive isotope of potassium $\mathrm{K}^{40}$ (Adams et al., 1956). Each rock type has its own specific radioactivity, may be produced $\alpha, \beta$ and $\mathrm{Y}$ rays. $\mathrm{U}^{235}$ ends with stable $\mathrm{pb}^{207}$, while $\mathrm{Th}^{232}$ ends with stable $\mathrm{pb}^{208}$. potassium $\left(\mathrm{K}^{40}\right)$ disintegrate to give argon $\mathrm{Ar}^{40}$, which is stable.

For studing radioactive elements (Th, U, Ra and K) in the soils of Wadi Nugurs, thirty three soil samples representing eleven soil profiles were analyzed by 
gamma-ray spectrometric techniques for measuring their uranium, thorium, radium and potassium isotope contents.

Data in Table (6) reveal that Th content of the studied soil profiles varied from 6 to $37 \mathrm{ppm}$, with an average mean ranged from 9 to $30.7 \mathrm{ppm}$. eU content ranged between 20 and $150 \mathrm{ppm}$, with an average varied from 33.3 to $104.3 \mathrm{ppm}$. Ra content in the studied soils ranged from 6 to $23 \mathrm{ppm}$, with an average varied from 7.0 to $14.3 \mathrm{ppm}$, while $\mathrm{K}$, isotope content ranged between 1.58 and $3.29 \%$ with an average varied between 1.8 and $2.8 \%$.

In the studied soil profiles, $\mathrm{eU}$ and Th contents are higher than $\mathrm{Ra}$ content. The studied soil samples contain relatively higher values of uranium element as a compared to the standard limiting the presence of uranium in the soils (less than 1 to $8 \mathrm{ppm}$.), published by IAEA 1988). Also, The average content of $U^{238}$ is still higher than that reported by the IAEA (1988).

It can be noticed that, the enrichment of uranium especially in Wadi Nugrus - Wadi Abu Rusheid area is due to uranium rich minerals most probably zircon $\left(\mathrm{ZrSO}_{4}\right)$ drived from the parent rocks, beside the altered zircon recored in the area and tifiedified by (XRD) . Altered zircon is found as accessory mineral derived from parent country rocks (Ibrahim et al 2004 and Saleh et al 2013). Accordingly, the previous profiles are enriched with Uranium and thorium radionuclides.

Table 6. eTh, eU, Ra and $\mathrm{K}$ contents of the studied soil profiles representing Wadi Nugrus:

\begin{tabular}{|c|c|c|c|c|c|}
\hline $\begin{array}{l}\text { Profile } \\
\text { No }\end{array}$ & $\begin{array}{l}\text { Depth } \\
\text { (cm) }\end{array}$ & $\begin{array}{c}\text { eTh } \\
\text { (ppm) }\end{array}$ & $\begin{array}{c}\mathrm{eU} \\
(\mathbf{p p m})\end{array}$ & $\begin{array}{c}\operatorname{Ra}(E u) \\
(p p m)\end{array}$ & K\% \\
\hline & $0-50$ & 34 & 104 & 23 & 2.53 \\
\hline \multirow[t]{3}{*}{1} & $50-100$ & 37 & 122 & 20 & 2.83 \\
\hline & $100-150$ & 21 & 88 & 15 & 2.72 \\
\hline & $0-50$ & 29 & 69 & 15 & 3.29 \\
\hline \multirow[t]{3}{*}{2} & $50-100$ & 24 & 63 & 13 & 2.37 \\
\hline & $100-150$ & 16 & 61 & 16 & 2.42 \\
\hline & $0-50$ & 10 & 32 & 8 & 2.58 \\
\hline \multirow[t]{3}{*}{3} & $50-100$ & 11 & 90 & 9 & 2.88 \\
\hline & $100-150$ & 12 & 34 & 10 & 2.58 \\
\hline & $0-50$ & 12 & 26 & 7 & 2.84 \\
\hline \multirow[t]{3}{*}{4} & $50-100$ & 7 & 100 & 6 & 2.73 \\
\hline & $100-150$ & 8 & 30 & 8 & 2.22 \\
\hline & $0-50$ & 9 & 20 & 6 & 2.81 \\
\hline \multirow[t]{3}{*}{5} & $50-100$ & 10 & 150 & 9 & 2.65 \\
\hline & $100-150$ & 9 & 22 & 6 & 2.82 \\
\hline & $0-50$ & 16 & 33 & 12 & 1.95 \\
\hline \multirow[t]{3}{*}{6} & $50-100$ & 9 & 58 & 11 & 2.45 \\
\hline & $100-150$ & 15 & 100 & 12 & 1.85 \\
\hline & $0-50$ & 17 & 39 & 13 & 2.25 \\
\hline \multirow[t]{3}{*}{7} & $50-100$ & 15 & 27 & 9 & 2.81 \\
\hline & $100-150$ & 10 & 34 & 11 & 2.45 \\
\hline & $0-50$ & 17 & 50 & 12 & 1.98 \\
\hline \multirow[t]{3}{*}{8} & $50-100$ & 8 & 32 & 8 & 1.75 \\
\hline & $100-150$ & 13 & 44 & 9 & 1.58 \\
\hline & $0-50$ & 22 & 49 & 14 & 2.34 \\
\hline \multirow[t]{3}{*}{9} & $50-100$ & 14 & 37 & 10 & 2.85 \\
\hline & $100-150$ & 17 & 29 & 12 & 2 \\
\hline & $0-50$ & 7 & 29 & 8 & 2.76 \\
\hline \multirow[t]{3}{*}{10} & $50-100$ & 6 & 122 & 6 & 2.55 \\
\hline & $100-150$ & 24 & 82 & 18 & 2.82 \\
\hline & $0-50$ & 13 & 51 & 15 & 2.34 \\
\hline \multirow[t]{2}{*}{11} & $50-100$ & 7 & 82 & 7 & 3.18 \\
\hline & $100-150$ & 19 & 95 & 17 & 2.41 \\
\hline
\end{tabular}

Radiation exposure rate and equivalent does rate in the studied area.

The radition exposure rate has been calculated from the apparent concentration of eU, eTh in (ppm) and $\mathrm{K}(\%)$ applying the following expression International Atomic Enerrgy Ageuey (IAEA1991):

Exposure $\operatorname{rate}(\mathrm{Ur} / \mathrm{H})=1.505 \mathrm{k}(\%)+0.653 \mathrm{Eu}(\mathrm{PPM})+0.287 \mathrm{eTh}(\mathrm{ppm})$.

The relation exposure raye can be converted to equivalent radiation does rate through the use of simple conversion factor as follows (IAEA 1979).

Does rate $(\mathrm{mSv} / \mathrm{y})=0.0833 *$ exposure rate $(\mathrm{Ur} / \mathrm{h})$

The International commission of Radiological Protection (I.C.R.P.) has recommended that no individual should receive more than 5000 millirems /year $(50 \mathrm{mSv} / \mathrm{y})$ rom all a natural and radiation source in human euvivonment (IAEAS. 1979),

(2000), the IAEA. Recommended that the does not exceed one Mill Sievert per year

Table 7. Exposure rate and equivalent does rate for the studied Nugrus Soil samples.

\begin{tabular}{|c|c|c|c|}
\hline $\begin{array}{l}\text { Profile } \\
\text { No. }\end{array}$ & $\begin{array}{l}\text { Depth } \\
\text { (cm) }\end{array}$ & $\begin{array}{c}\text { Exposure Rate } \\
(\mathrm{Ur} / \mathrm{h})\end{array}$ & $\begin{array}{l}\text { Equivalent does } \\
\text { rate }(\mathrm{mSv} / \mathrm{y})\end{array}$ \\
\hline \multirow{4}{*}{1} & $0-50$ & 81.48 & 6.697 \\
\hline & $50-100$ & 92.10 & 7.672 \\
\hline & $100-150$ & 65.82 & 5.483 \\
\hline & $0-50$ & 68.98 & 5.746 \\
\hline \multirow{2}{*}{2} & $50-100$ & 54.13 & 4.509 \\
\hline & $100-150$ & 46.85 & 3.903 \\
\hline \multirow{4}{*}{3} & $0-50$ & 27.00 & 2.249 \\
\hline & $50-100$ & 64.46 & 5.370 \\
\hline & $100-150$ & 28.85 & 2.403 \\
\hline & $0-50$ & 24.18 & 3.763 \\
\hline \multirow{3}{*}{4} & $50-100$ & 69.42 & 5.783 \\
\hline & $100-150$ & 24.83 & 2.052 \\
\hline & $0-50$ & 19.47 & 1.622 \\
\hline \multirow{3}{*}{5} & $50-100$ & 101.81 & 8.481 \\
\hline & $100-150$ & 20.75 & 1.728 \\
\hline & $0-50$ & 28.42 & 2.367 \\
\hline \multirow{3}{*}{6} & $50-100$ & 42.98 & 3.580 \\
\hline & $100-150$ & 70.39 & 5.863 \\
\hline & $0-50$ & 32.95 & 2.745 \\
\hline \multirow{3}{*}{7} & $50-100$ & 25.63 & 2.135 \\
\hline & $100-150$ & 28.08 & 2.339 \\
\hline & $0-50$ & 33.96 & 2.829 \\
\hline \multirow{2}{*}{8} & $50-100$ & 25.19 & 2.098 \\
\hline & $100-150$ & 33.96 & 2.829 \\
\hline \multirow{4}{*}{9} & $0-50$ & 40.85 & 3.403 \\
\hline & $50-100$ & 31.73 & 2.643 \\
\hline & $100-150$ & 26.25 & 2.187 \\
\hline & $0-50$ & 24.52 & 2.043 \\
\hline \multirow{2}{*}{10} & $50-100$ & 82.79 & 6.896 \\
\hline & $100-150$ & 63.04 & 5.251 \\
\hline \multirow{3}{*}{11} & $0-50$ & 39.54 & 3.294 \\
\hline & $50-100$ & 58.70 & 4.890 \\
\hline & $100-150$ & 69.22 & 5.767 \\
\hline
\end{tabular}

In the study area and from Table (7), the highest value of does reach $8.481 \mathrm{mSv} / \mathrm{y}$ was recorded in the subsurface layer of profile 5, while the lowest value $1.622 \mathrm{mSv} / \mathrm{y}$ was detected in the surface layer of the same profile. These values are in the high side and in 
the maximum radiation does rate with harm to the individuals with continues external radiation for the whale body.

From the previous discussion it is found that the main component of soil are quartz, Calcite, Kaolinite and accessory minerals showing that they are drived from igneous rocks. The major elements analysis shows the dominance of $\mathrm{SiO}_{2}, \mathrm{Al}_{2} \mathrm{O}_{3}$ and $\mathrm{Fe}_{2} \mathrm{O}_{3}$ oxides, while trace elements are characterized by low concentration except that of $\mathrm{Cr}, \mathrm{Cu}, \mathrm{Zn}, \mathrm{Rb}, \mathrm{Y}, \mathrm{Pb}$ and $\mathrm{Nb}$. The $\mathrm{U}$ concentration ranges between 20 and 150 ppm., K40 ranges from 1.58 to $3.29 \%$, while that of Th content ranges between 6 and $37 \mathrm{ppm}$. Declaring that Wadi Nugrus area is high radioactive area.

\section{REFERENCES}

Adams , J. A. S., J. K. Osman and J. J. W. Rogers. (1956): The geochemistry of thorium and uranium . In . physical and chemistry of the earth, 3, p. 298-348, pergamon press, New York.

Aubert, H. and M. Pinta. (1977): Trace elements in soils. Elsevier Scientific Publishing Co. , Amsterdam, Nether lands.

El- Gaby, S.; O. M. El- Nady and A. A. Khudeir. (1984): Tectonic evolution of the basement complex in the CED of Egypt . Geol 73, p. 10191036.

EL Reedy, M.W., A.F. Kamel and S. E. L. Mansour. (1988): Contribution to the radioactivity of Um Ara granitic pluton, South-Eastern Desert ,EgypT, $4^{\text {th }}$ Conf .Nucl. Sci and Appl., I. p. 149155.

FAO and UNESCO. (1974): Soil map of the World legend paris., Vol . I, 40p.

Ibrahim, M. E.; A. A. Abd El-Waahed; F.M. Khaleal; G. M. Mansour and K. Wata nabe (2007): Compartive study between alkaline and calcalkaline lamprophyres in Abu Rusheid area South Eastern Desert, Egypt [c]. The 10 international minig petroleum and Metallurgical Engineering Conferreuce, March, 6-8, p.99-115.
Ibrahim, M. E.; H. S. Assaf and G. M. Saleh (2000): Geochemical alteration and spectrometric analysis in Abu Rusheid altered uraniferous gneissose granites, South Eastern Desert,Egypt. Chem. Erde, Vol. 60, p.173-188.

International Atomic Energy Agency (IAEA), (1991): In $U$ Exploration and ore processes, Vienna Tech. Rep., 341, 42p.

International Atomic Energy Agency (IAEA), (1998): Principles for the Exemption of Radiation Sources and Practices from Radiological Control. Report safety Series, No. 89, pp: 56-68.

International Atomic Energy Agency IAEA, (1979): Gamma ray Survey in uranium exploration, Technical Report Series, Vienna paper No. 186, p.90.

Matolin, M. (1999): Construction and use of spectrometric cliobration pads. IAEA Project Egy/4/030-03, IAEA, Vienna, p.14.

Norrish, K. and B.W. Chappell (1967): X-ray fluorescence spectrography. In: Zussman, J. (ed.), Physical Methods in Determinative Mineralogy, Academic Press, New York, p.161214.

Oraby, F.; E. A. Abu El- Hassan; S. Omar; F. M. Khaled and M. H. Mohamed (2003): Delimitation and elevation of berlyum resource in the Eastern Desert of Egypt (Internal Report p. 66.)

Saleh, G.M., F.O. Mahmoud; A.A. Abu El Hassan; M.A. Rashed; F.M. Khaleal, and M.A. Mahmoud and others (2013): Mineral Resources Estimations in the Cataclastic rocks of $\mathrm{Abu}$ Rusheid area, South Eastern Desert, Egypt. (Internal report) $195 \mathrm{p}$.

Shapiro, Land Brannock, W.W. (1962) Rapid analysis of silicate carbonate and phosphate rocks ,US GEOL. SURV Bull., 1144-A56p.

USDA (2004): Soil Laboratory Methods, soil survey investigation, report No. 42 version 4.0 November 2004.

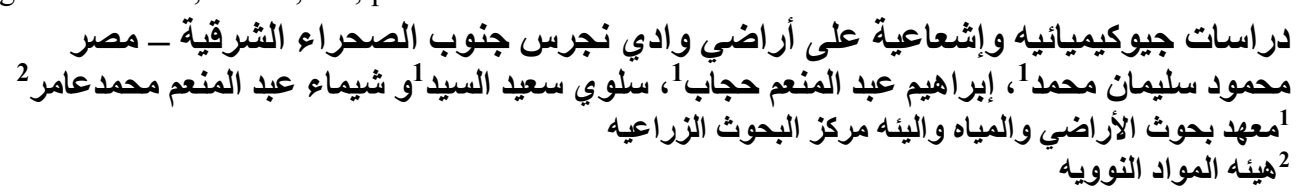

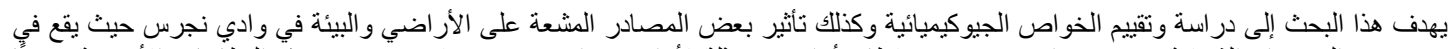

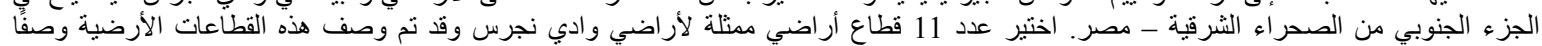

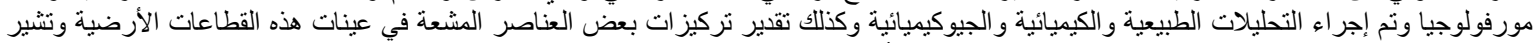

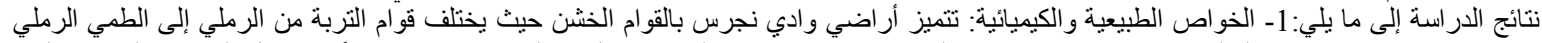

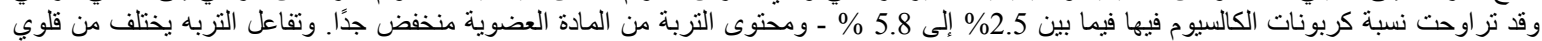

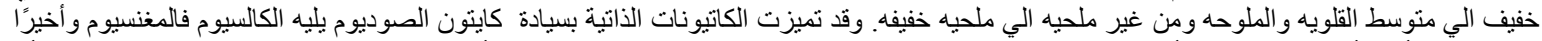

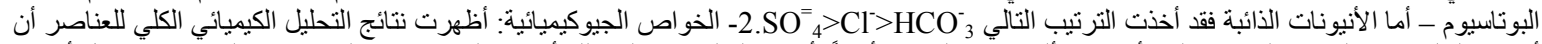

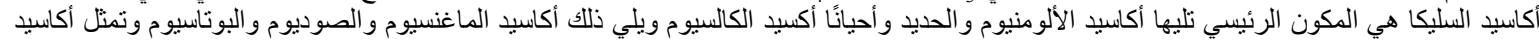

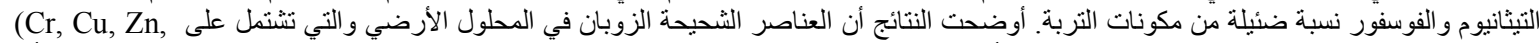

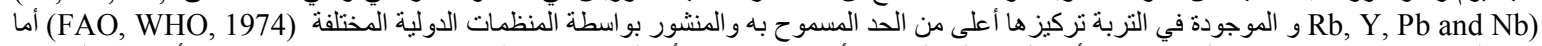

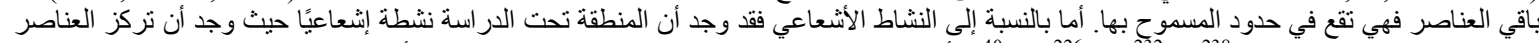

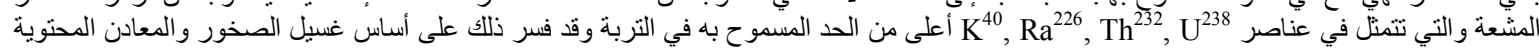
على عنصر "اليور انيوم وكذللك إدمصاص اليور انيوم على المو اد الـ Ferruginous، وكذلك على سطوح معلى معادن الطين. 